\title{
EFFECTS OF TEMPERATURE AND PRESSURE TIME IN THE MANUFACTURE OF PARTICLEBOARDS
}

\author{
Setsuo Iwakiri ${ }^{1}$, Rosilani Trianoski ${ }^{1}$, Thiago Souza da Rosa ${ }^{2}$, Leandro de Sousa Silva da Costa ${ }^{3}$ \\ $1^{1 *}$ Federal University of Paraná, Department of Forest Engineering and Technology, Curitiba, Paraná, Brazil - \\ setsuo.ufpr@gmail.com*,rosilani@ufpr.br \\ ${ }^{2}$ Federal University of Paraná, Post-Graduation Program in Forest Engineering, Curitiba, PR, Brazil - thiagosouzadarosa@ gmail.com \\ ${ }^{3}$ Federal University of Paraná, Wood Industrial Engineering Course, Curitiba, Paraná, Brazil - leandrocosta88@ gmail.com
}

Received for publication: 13/06/2017 - Accepted for publication: 28/02/2019

\begin{abstract}
Resumo
Efeitos da temperatura e tempo de prensagem na manufatura de painéis aglomerados $\mathrm{O}$ objetivo deste trabalho foi avaliar os efeitos de três diferentes temperaturas e tempos de prensagem, próximas às condições industriais, sobre as propriedades de painéis experimentais produzidos em laboratório. Os painéis foram produzidos com densidade nominal de $0,70 \mathrm{~g} / \mathrm{cm}^{3}$, com $8 \%$ de resina ureia-formaldeído e prensados à temperatura de 180,200 e $220^{\circ} \mathrm{C}$ e tempo de 2 , 4 e 6 minutos. Os painéis foram produzidos com densidade nominal de $0,70 \mathrm{~g} / \mathrm{cm}^{3}$, com $8 \%$ de resina ureia-formaldeído e prensados à temperatura de 180,200 e $220^{\circ} \mathrm{C}$ e tempo de 2,4 e 6 minutos $\mathrm{O}$ aumento no tempo de prensagem não afetou de forma significativa as propriedades físicas dos painéis, porém melhorou as suas propriedades mecânicas. Já o aumento na temperatura de prensagem afetou de forma negativa as propriedades mecânicas dos painéis.

Palavras-chave Parâmetros de prensagem; propriedades dos painéis; transferência de calor.
\end{abstract}

\section{Abstract}

The objective of this work was to evaluate the effects of three different temperatures and pressing times, near of industrial conditions, on the properties of experimental panels produced in the laboratory. The objective of this work was to evaluate the effects of three different temperatures and pressing times, near of industrial conditions, on the properties of experimental panels produced in the laboratory. The objective of this work was to evaluate the effects of three different temperatures and pressing times, near of industrial conditions, on the properties of experimental panels produced in the laboratory. The increase in the pressing time did not significantly affect the physical properties of the panels but improved their mechanical properties. The increase in the pressing temperature reduced the mechanical properties of the panels.

Keywords: Press parameters; properties of the panels; heat transfer.

\section{INTRODUCTION}

The pressing process is considered the most critical stage for the production of particleboards, since their final properties are directly related to pressure, temperature and time levels established in the press according to the production plan.

The main function of the temperature during the pressing process is to accelerate the polymerization of the resin distributed between wood particles. In this step, the densification of the material occurs by a mechanical process of deformation by bending and compression until the final thickness, a heating of the material and consequently a chemical process that leads to curing of the resin (MALONEY, 1993).

The pressing temperature is defined according to the type of resin used (KELLY, 1977; MARRA, 1992). The heat transfer rate occurs from the surface layers to the center of the panel, where in the first moments of pressing, steam formation occurs on the faces of the mattress, then, plasticizing the wood and facilitating its compression until it reaches the ultimate thickness. Albuquerque and Iwakiri (2016) report that when using ureaformaldehyde resin, temperature above $93^{\circ} \mathrm{C}$ in the core of the panel for 15 seconds is enough for curing.

The press temperature directly affects the productivity of a manufacturing unit, since higher press temperatures result in a shorter panel pressing time (IWAKIRI, 2005). In general, with increasing temperature, the mechanical properties tend to increase. However, Wilcox (1953), using a pressing temperature of $240^{\circ} \mathrm{C}$, found a considerable decline in the flexural strength of the panels, as a result of the degradation of the crystalline structure of the cellulosic chain. Additionally, Suleiman (1999) argues that, in addition to changing physical behavior, too high temperatures affect heat conduction capacity.

FLORESTA, Curitiba, PR, v. 49, n. 3, p. 383 - 390, jul/set 2019.

Iwakiri, S. et.al.

ISSN eletrônico 1982-4688 
The pressing time is the time elapsed between the moment of consolidation of the particleboard to the final thickness of the panel and the opening time of the press plates (MOSLEMI, 1974). According to Marra (1992), the pressing time must be sufficient for the interior of the panel to reach the temperature required for polymerization of the resin. In addition, the author reports that the pressing time exerts significant influence on the properties of the panels, thickness control and surface quality.

According to Albuquerque and Iwakiri (2016), the pressing time depends mainly on the heat transfer efficiency, the panel thickness, the temperature, the moisture distribution in the mattress, and generally can be defined at about 6 to 12 seconds per mm thickness of the panel. Moslemi (1974) states that the reduction in the time of consolidation of the panels is economically desirable, as they imply higher productivity as well as reduction in energy consumption, nevertheless, the decrease in the pressing time also results in the reduction of resistance properties.

On the one hand, agglomerated panel industries employ temperatures of 200 to $220^{\circ} \mathrm{C}$ and pressing time, or, press factor, of 6 to 12 seconds per mm of panel thickness. On the other hand, at the laboratory level, temperatures of 140 to $160^{\circ} \mathrm{C}$, specific pressure of $4 \mathrm{MPa}$ and pressing time of 8 minutes, are usually employed for panels with resin-based bonding of urea-formaldehyde resin and thickness of $15 \mathrm{~mm}$. Therefore, there are different pressing conditions, even considering the small dimensions of experimental panels.

Thus, the objective of this study was to evaluate the effects of three different temperatures and pressing times near of industrial conditions on the properties of experimental panels produced in the laboratory.

\section{MATERIAL AND METHODS}

In order to perform this research, industrial particles of Pinus were collected from an agglomerated panel industry in the metropolitan region of Curitiba, Paraná State, Brazil. The particles were reprocessed in a hammer mill, dried at a medium humidity content of $3 \%$, and classified in a $0.6 \mathrm{~mm}$ mesh screen to remove "thins".

The experimental panels were produced with nominal density of $0.70 \mathrm{~g} / \mathrm{cm}^{3}$ and dimensions of $50 \times 38 \times 1,30 \mathrm{~cm}$, with $8 \%$ of urea-formaldehyde resin and $1 \%$ of paraffinic emulsion. The panels were pressed with three different times and press temperatures, simulating the industrial conditions, being 2,4 and 6 minutes and 180,200 and $220^{\circ} \mathrm{C}$, respectively. The experimental design is presented in Table 1 . The applied pressure was 4.0 $\mathrm{MPa}$ and three panels were produced per treatment, totaling 27 panels.

Table 1. Experimental design

Tabela 1. Delineamento experimental

\begin{tabular}{|c|c|c|}
\hline Treatment & Temperature $\left({ }^{\circ} \mathrm{C}\right)$ & Pressing time (min) \\
\hline $\mathrm{T} 1-180 / 2$ & 180 & \\
\hline $\mathrm{T} 2-200 / 2$ & 200 & 2. \\
\hline $\mathrm{T} 2-220 / 2$ & 220 & \\
\hline $\mathrm{T} 4-180 / 4$ & 180 & \\
\hline T5 - 200/4 & 200 & 4. \\
\hline T6 - 220/4 & 220 & \\
\hline $\mathrm{T} 7-180 / 6$ & 180 & \\
\hline T8 - 200/6 & 200 & 6. \\
\hline T9 - 220/6 & 220 & \\
\hline
\end{tabular}

After pressing, the panels were squared and conditioned in a climatic chamber at a temperature of $20 \pm^{\circ}$ $\mathrm{C}$ and relative humidity of $65 \pm 3 \%$, until stabilized at a mean humidity content of $12 \%$.

For the evaluation of the physical-mechanical properties, five specimens of each panel were tested for density, five for static bending, five for internal bond, and five for water absorption and thickness swelling after 2 and 24 hours of immersion in water. In this way, the tests were based on the procedures described in standards EN 323 (2002), EN 310 (2002), EN 319 (2002) and EN 317 (2002), respectively. The results of the tests of modulus of rupture, modulus of elasticity and internal bond were compared with the requirements of standard EN 312-3 (P3) for panels destinated for interior use (including furniture) in dry conditions, with a thickness of more than 13 $\mathrm{mm}$.

The statistical stablishment was in a factorial arrangement $(3 \times 3)$, being three times and three temperatures. For the statistical analysis of the results, it was applied Grubbs tests to identify outliers, Shapiro Wilks for data normality, Bartllet for homogeneity of variance, ANOVA and Tukey for averages comparison. All to $95 \%$ reliability in the statistical package Sthatgraphics. 


\section{RESULTS}

\section{Physical properties of the panels}

Table 2 shows the mean density results, water absorption and thickness swelling after 2 and 24 hours immersion in water.

Table 2. Averages of the physical properties of the panels.

Tabela 2. Valores médios das propriedades físicas dos painéis.

\begin{tabular}{|c|c|c|c|c|c|}
\hline Treatment & $\begin{array}{l}\text { Density } \\
\left(\text { g.cm }^{-3}\right)\end{array}$ & $\begin{array}{l}\text { WA2h } \\
(\%)\end{array}$ & $\begin{array}{l}\text { WA24h } \\
(\%)\end{array}$ & $\begin{array}{l}\text { TS2h } \\
(\%)\end{array}$ & $\begin{array}{l}\text { TS24h } \\
(\%)\end{array}$ \\
\hline $\mathrm{T} 1-180^{\circ} \mathrm{C} / 2 \mathrm{~min}$ & $\begin{array}{l}0.685 \mathrm{a} \\
(5.90)\end{array}$ & $\begin{array}{l}18.65 \mathrm{ab} \\
(21.10)\end{array}$ & $\begin{array}{l}59.16 \mathrm{c} \\
(13.33)\end{array}$ & $\begin{array}{l}6.75 \mathrm{ab} \\
(16.07)\end{array}$ & $\begin{array}{l}21.21 \mathrm{bc} \\
(9.48)\end{array}$ \\
\hline $\mathrm{T} 2-200^{\circ} \mathrm{C} / 2 \mathrm{~min}$ & $\begin{array}{l}0.673 \mathrm{a} \\
(4.95)\end{array}$ & $\begin{array}{l}20.00 \mathrm{ab} \\
(21.89)\end{array}$ & $\begin{array}{l}70.05 \mathrm{a} \\
(9.80)\end{array}$ & $\begin{array}{l}6.82 \mathrm{ab} \\
(19.08)\end{array}$ & $\begin{array}{l}23.71 \mathrm{ab} \\
(12.56)\end{array}$ \\
\hline $\mathrm{T} 3-220^{\circ} \mathrm{C} / 2 \mathrm{~min}$ & $\begin{array}{l}0.675 \mathrm{a} \\
(6.10)\end{array}$ & $\begin{array}{l}22,43 \mathrm{a} \\
(14.75)\end{array}$ & $\begin{array}{l}66.66 \mathrm{ab} \\
(7.46)\end{array}$ & $\begin{array}{l}8,35 \mathrm{a} \\
(18.44)\end{array}$ & $\begin{array}{l}26,26 \mathrm{a} \\
(9.26)\end{array}$ \\
\hline $\mathrm{T} 4-180^{\circ} \mathrm{C} / 4 \mathrm{~min}$ & $\begin{array}{l}0.679 \mathrm{a} \\
(5.64)\end{array}$ & $\begin{array}{l}16,66 \mathrm{~b} \\
(22.58)\end{array}$ & $\begin{array}{l}65.23 \mathrm{ABC} \\
(10.10)\end{array}$ & $\begin{array}{l}5.84 \mathrm{c} \\
(33.47)\end{array}$ & $\begin{array}{l}23.64 \mathrm{ab} \\
(14.16)\end{array}$ \\
\hline $\mathrm{T} 5-200^{\circ} \mathrm{C} / 4 \mathrm{~min}$ & $\begin{array}{l}0.683 \mathrm{a} \\
(5.63)\end{array}$ & $\begin{array}{l}19.36 \mathrm{ab} \\
(15.37)\end{array}$ & $\begin{array}{l}62,80 \mathrm{bc} \\
(10.44)\end{array}$ & $\begin{array}{l}7.22 \mathrm{ab} \\
(16.06)\end{array}$ & $\begin{array}{l}23.78 \mathrm{ab} \\
(16.25)\end{array}$ \\
\hline $\mathrm{T} 6-220^{\circ} \mathrm{C} / 4 \mathrm{~min}$ & $\begin{array}{l}0.687 \mathrm{a} \\
(6.05)\end{array}$ & $\begin{array}{l}19.09 \mathrm{ab} \\
(12.28)\end{array}$ & $\begin{array}{l}59.26 \mathrm{c} \\
(6.10)\end{array}$ & $\begin{array}{l}7.18 \mathrm{ab} \\
(16.25)\end{array}$ & $\begin{array}{l}24.23 \mathrm{ab} \\
(9.42)\end{array}$ \\
\hline $\mathrm{T} 7-180^{\circ} \mathrm{C} / 6 \mathrm{~min}$ & $\begin{array}{c}0.684 \mathrm{a} \\
(6.96)\end{array}$ & $\begin{array}{l}19,87 \mathrm{~b} \\
(23.25)\end{array}$ & $\begin{array}{l}61,00 \mathrm{bc} \\
(9.25)\end{array}$ & $\begin{array}{l}7.20 \mathrm{ab} \\
(19.91)\end{array}$ & $\begin{array}{l}24.45 \mathrm{ab} \\
(8.80)\end{array}$ \\
\hline $\mathrm{T} 8-200^{\circ} \mathrm{C} / 6 \mathrm{~min}$ & $\begin{array}{l}0.692 \mathrm{a} \\
(7.53)\end{array}$ & $\begin{array}{l}17,10 \mathrm{~b} \\
(18.87)\end{array}$ & $\begin{array}{l}60,65 \text { bc } \\
(9.43)\end{array}$ & $\begin{array}{l}7,67 \mathrm{a} \\
(22.46)\end{array}$ & $\begin{array}{l}23.67 \mathrm{ab} \\
(12.12)\end{array}$ \\
\hline $\mathrm{T} 9-220^{\circ} \mathrm{C} / 6 \mathrm{~min}$ & $\begin{array}{l}0.701 \mathrm{a} \\
(6.56)\end{array}$ & $\begin{array}{l}19.31 \mathrm{ab} \\
(13.97)\end{array}$ & $\begin{array}{l}50.83 \mathrm{~d} \\
(9.17)\end{array}$ & $\begin{array}{l}7,61 \mathrm{a} \\
(18.53)\end{array}$ & $\begin{array}{l}18.65 \mathrm{c} \\
(18.16)\end{array}$ \\
\hline
\end{tabular}

WA2h: water absorption after 2 hours; WA24h: water absorption after 24 hours; TS2h: thickness swelling after 2 hours; TS24h: thickness swelling after 2 hours.

Averages followed by the same letter in the same column are statistically the same by the Tukey test at $95 \%$ reliability. Values in parentheses refer to the coefficient of variation in percentage.

The density averages ranged from $0.673 \mathrm{~g} . \mathrm{cm}^{-3}$ for the panels $\mathrm{T} 2\left(200^{\circ} \mathrm{C} / 2 \mathrm{~min}\right)$ at $0.701 \mathrm{~g} \mathrm{~cm}^{-3}$ for the $\mathrm{T} 9$ panels $\left(220^{\circ} \mathrm{C} / 6 \mathrm{~min}\right)$. There were no significant differences between treatments.

The WA2h averages ranged from $16.66 \%$ for T4 panels $\left(180^{\circ} \mathrm{C} / 4 \mathrm{~min}\right)$ to $22.43 \%$ for $\mathrm{T} 3$ panels $\left(220^{\circ} \mathrm{C} / 2\right.$ $\mathrm{min})$, the averages being statistically different from each other. The $\mathrm{T} 4$ panels $\left(180^{\circ} \mathrm{C} / 4 \mathrm{~min}\right)$ had a statistically lower average in relation to the $\mathrm{T} 3$ panels $\left(220^{\circ} \mathrm{C} / 2 \mathrm{~min}\right)$ and the same in comparison to the other treatments.

For the WA24h, the averages varied from $50.83 \%$ for $\mathrm{T} 9$ panels $\left(220^{\circ} \mathrm{C} / 6 \mathrm{~min}\right)$ to $70.05 \%$ for $\mathrm{T} 2$ panels $\left(200^{\circ} \mathrm{C} / 2 \mathrm{~min}\right)$, being the averages statistically different between themselves. The T9 panels $\left(220^{\circ} \mathrm{C} / 6 \mathrm{~min}\right)$ presented a statistically lower average compared to all other treatments.

The TS2h averages ranged from $5.84 \%$ for $\mathrm{T} 4$ panels $\left(180^{\circ} \mathrm{C} / 4 \mathrm{~min}\right)$ to $8.35 \%$ for $\mathrm{T} 3$ panels $\left(220^{\circ} \mathrm{C} / 2\right.$ $\mathrm{min})$, the averages being statistically different from each other. The $\mathrm{T} 4$ panels $\left(180^{\circ} \mathrm{C} / 4 \mathrm{~min}\right)$ presented a statistically lower average compared to all other treatments.

For TS24h, the averages ranged from $18.64 \%$ for T9 panels $\left(220^{\circ} \mathrm{C} / 6 \mathrm{~min}\right)$ to $26.26 \%$ for $\mathrm{T} 3$ panels $\left(220^{\circ} \mathrm{C} / 2 \mathrm{~min}\right)$, the averages being statistically different from each other. The T9 panels $\left(220^{\circ} \mathrm{C} / 6 \mathrm{~min}\right) \mathrm{had}$ a statistically equal average in relation to $\mathrm{T} 1$ panels $\left(220^{\circ} \mathrm{C} / 2 \mathrm{~min}\right)$ and the same average in comparison to the other treatments.

FLORESTA, Curitiba, PR, v. 49, n. 3, p. 383 - 390, jul/set 2019.

Iwakiri, S. et.al.

ISSN eletrônico 1982-4688 
Table 3 shows the effects of pressing time on water absorption and swelling in thickness after 2 and 24 hours of immersion in water.

Table 3. Effects of pressing time on the physical properties of the panels.

Tabela 3. Efeitos do tempo de prensagem sobre as propriedades físicas dos painéis.

\begin{tabular}{lllll}
\hline Time & $\begin{array}{l}\text { WA 2h } \\
(\boldsymbol{\%})\end{array}$ & $\begin{array}{l}\text { WA 24h } \\
(\boldsymbol{\%})\end{array}$ & $\begin{array}{l}\text { TS 2h } \\
(\boldsymbol{\%})\end{array}$ & $\begin{array}{l}\text { TS 24h } \\
(\boldsymbol{\%})\end{array}$ \\
\hline 2 min. & $20,36 \mathrm{a}$ & $65.29 \mathrm{a}$ & $7,31 \mathrm{a}$ & $23,73 \mathrm{a}$ \\
& $(20.46)$ & $(12.24)$ & $(20.39)$ & $(13.55)$ \\
4 min. & $18,45 \mathrm{~b}$ & $62.30 \mathrm{a}$ & $6,81 \mathrm{a}$ & $23,89 \mathrm{a}$ \\
& $(17.36)$ & $(10.23)$ & $(21.91)$ & $(13.22)$ \\
6 min. & $18,22 \mathrm{~b}$ & $57.57 \mathrm{~b}$ & $7,48 \mathrm{a}$ & $22,31 \mathrm{a}$ \\
& $(17.56)$ & $(12.28)$ & $(20,11)$ & $(16.99)$ \\
\hline
\end{tabular}

Averages followed by the same letter in the same column are statistically the same by the Tukey test at $95 \%$ reliability. Values in parentheses refer to the coefficient of variation in percentage.

The results of the factorial analysis indicated that there was influence of the pressing time on the average values of WA2h and WA24h. No significant differences were found for TS2h and TS24h for different pressing times of the panels.

Table 4 shows the effects of pressing time onWA2h, WA24h, TS2h and |TS24h.

Table 4. Effects of pressing time on the physical properties of the panels. Tabela 4. Effect of pressing time on the physical properties of panels.

\begin{tabular}{lllll}
\hline Temperature & $\begin{array}{l}\text { WA } \mathbf{~ h ~} \\
(\boldsymbol{\%})\end{array}$ & $\begin{array}{l}\text { WA } 24 \mathbf{h} \\
(\boldsymbol{\%})\end{array}$ & $\begin{array}{l}\text { TS 2h } \\
(\boldsymbol{\%})\end{array}$ & $\begin{array}{l}\text { TS 24h } \\
(\%)\end{array}$ \\
\hline $180^{\circ} \mathrm{C}$ & $17.88 \mathrm{~b}$ & $61.64 \mathrm{ab}$ & $6.65 \mathrm{~b}$ & $23.08 \mathrm{a}$ \\
& $(21.03)$ & $(11.48)$ & $(23.45)$ & $(12.34)$ \\
$200^{\circ} \mathrm{C}$ & $18.85 \mathrm{ab}$ & $64.59 \mathrm{a}$ & $7.23 \mathrm{ab}$ & $23.72 \mathrm{a}$ \\
& $(19.71)$ & $(17.57)$ & $(19.62)$ & $(13.49)$ \\
$220^{\circ} \mathrm{C}$ & $20.29 \mathrm{a}$ & $59.10 \mathrm{~b}$ & $7.71 \mathrm{a}$ & $23.15 \mathrm{a}$ \\
& $(15.56)$ & $(13.59)$ & $(18.13)$ & $(18.05)$ \\
\hline
\end{tabular}

Averages followed by the same letter in the same column are statistically the same by the Tukey test at $95 \%$ reliability. Values in parentheses refer to the coefficient of variation in percentage.

The results of the factorial analysis presented in Table 4 showed that, except for the TS24h, there was influence of the pressing temperature on the average values of WA2h and WA24h and TS2h.

\section{Mechanical properties of panels}

Table 5 shows the average results of modulus of rupture, modulus of elasticity and internal bond.

Table 5. Averages of the mechanicals properties of the panels.

Tabela 5. Resultados médios das propriedades mecânicas dos painéis.

\begin{tabular}{llll}
\hline Treatment & $\begin{array}{l}\text { MOR } \\
(\mathbf{M P a})\end{array}$ & $\begin{array}{l}\text { MOE } \\
(\mathbf{M P a})\end{array}$ & $\begin{array}{l}\text { IB } \\
(\mathbf{M P a})\end{array}$ \\
\hline $\mathrm{T} 1-180^{\circ} \mathrm{C} / 2 \mathrm{~min}$ & $11.68 \mathrm{a}$ & $1.987 \mathrm{ab}$ & $0,62 \mathrm{~b}$ \\
& $(7.41)$ & $(9.78)$ & $(13,94)$ \\
$\mathrm{T} 2-200^{\circ} \mathrm{C} / 2 \mathrm{~min}$ & $8.71 \mathrm{c}$ & $1.711 \mathrm{ab}$ & $0.38 \mathrm{c}$ \\
& $(14,00)$ & $(14.75)$ & $(14.55)$
\end{tabular}




\begin{tabular}{llll}
$\mathrm{T} 3-220^{\circ} \mathrm{C} / 2 \mathrm{~min}$ & $7.88 \mathrm{c}$ & $1.648 \mathrm{~b}$ & $0.35 \mathrm{c}$ \\
& $(14.04)$ & $(14.23)$ & $(20.34)$ \\
\hline $\mathrm{T} 4-180^{\circ} \mathrm{C} / 4 \mathrm{~min}$ & $11.73 \mathrm{ab}$ & $1.877 \mathrm{ab}$ & $0.70 \mathrm{ab}$ \\
& $(8.76)$ & $(13.72)$ & $(17.34)$ \\
$\mathrm{T} 5-200^{\circ} \mathrm{C} / 4 \mathrm{~min}$ & $10,65 \mathrm{~b}$ & $1.849 \mathrm{ab}$ & $0.69 \mathrm{ab}$ \\
& $(8.47)$ & $(10.39)$ & $(20.87)$ \\
$\mathrm{T} 6-220^{\circ} \mathrm{C} / 4 \mathrm{~min}$ & $8.44 \mathrm{c}$ & $1.769 \mathrm{ab}$ & $0.45 \mathrm{c}$ \\
& $(15.52)$ & $(15.98)$ & $(17.12)$ \\
\hline $\mathrm{T} 7-180^{\circ} \mathrm{C} / 6 \mathrm{~min}$ & $11.48 \mathrm{ab}$ & $1.870 \mathrm{ab}$ & $0,74 \mathrm{a}$ \\
& $(11.12)$ & $(16.99)$ & $(13.61)$ \\
$\mathrm{T} 8-200^{\circ} \mathrm{C} / 6 \min$ & $12.31 \mathrm{a}$ & $1993 \mathrm{a}$ & $0.73 \mathrm{ab}$ \\
& $(12.86)$ & $(12.11)$ & $(19.05)$ \\
$\mathrm{T} 9-220^{\circ} \mathrm{C} / 6 \mathrm{~min}$ & $10,54 \mathrm{~b}$ & $1.702 \mathrm{~b}$ & $0.73 \mathrm{ab}$ \\
& $(15.01)$ & $(16.98)$ & $(13.79)$
\end{tabular}

MOR: modulus of rupture; MOE: modulus of elasticity; IB: internal bond; averages followed by the same letter in the same column are statistically the same by the Tukey test at $95 \%$ reliability. Values in parentheses refer to the coefficient of variation in percentage.

The average values of MOR ranged from 7.88 MPa for T3 panels (220 C/2 min) to $12.31 \mathrm{MPa}$ for T8 panels $\left(200^{\circ} \mathrm{C} / 6 \mathrm{~min}\right)$, the averages being statistically different from each other. The T8 panels $\left(220^{\circ} \mathrm{C} / 6 \mathrm{~min}\right)$ had a statistically equal average in relation to the $\mathrm{T} 1$ panels $\left(180^{\circ} \mathrm{C} / 2 \mathrm{~min}\right), \mathrm{T} 4\left(180^{\circ} \mathrm{C} / 6 \mathrm{~min}\right)$ and superior mean in comparison to the other treatments.

The average values of MOE ranged from $1.993 \mathrm{MPa}$ for $\mathrm{T} 8$ panels $\left(220^{\circ} \mathrm{C} / 6 \mathrm{~min}\right)$ to $1.648 \mathrm{MPa}$ for $\mathrm{T} 8$ panels $\left(200^{\circ} \mathrm{C} / 2 \mathrm{~min}\right)$, the averages being statistically different from each other. The $\mathrm{T} 8$ panels $\left(220^{\circ} \mathrm{C} / 6 \mathrm{~min}\right)$ had a statistically equal average in relation to the $\mathrm{T} 3$ panels $\left(220^{\circ} \mathrm{C} / 2 \mathrm{~min}\right), \mathrm{T} 9\left(220^{\circ} \mathrm{C} / 6 \mathrm{~min}\right)$ had superior average in comparison to the other treatments.

The average values of IB ranged from $0.35 \mathrm{MPa}$ for $\mathrm{T} 3$ panels $\left(220^{\circ} \mathrm{C} / 2 \mathrm{~min}\right)$ to $0.74 \mathrm{MPa}$ for $\mathrm{T} 7$ panels $\left(180^{\circ} \mathrm{C} / 6 \mathrm{~min}\right)$, the averages being statistically different from each other. The $\mathrm{T} 7$ panels $\left(180^{\circ} \mathrm{C} / 6 \mathrm{~min}\right)$ presented a statistically equal average in relation to the $\mathrm{T} 4$ panels $\left(180^{\circ} \mathrm{C} / 4 \mathrm{~min}\right), \mathrm{T} 5\left(200^{\circ} \mathrm{C} / 4 \mathrm{~min}\right), \mathrm{T} 8\left(220^{\circ} \mathrm{C} / 6 \mathrm{~min}\right)$ and $\mathrm{T} 9\left(220^{\circ} \mathrm{C} / 6 \mathrm{~min}\right)$ had superior average in comparison to the other treatments.

Table 6 shows the effects of pressing time on MOR, MOE and IB.

Table 6. Effects of pressing time on the mechanical properties of the panels.

Tabela 6. Efeitos do tempo de prensagem sobre as propriedades mecânicas dos painéis.

\begin{tabular}{llll}
\hline Time & $\begin{array}{l}\text { MOR } \\
(\mathbf{M P a})\end{array}$ & $\begin{array}{l}\text { MOE } \\
(\mathbf{M P a})\end{array}$ & $\begin{array}{l}\text { IB } \\
(\mathbf{M P a})\end{array}$ \\
\hline 2 min. & $9,46 \mathrm{~b}$ & $1875 \mathrm{a}$ & $0.45 \mathrm{c}$ \\
& $(20.70)$ & $(15.02)$ & $(30.95)$ \\
$4 \mathrm{~min}$. & $9,73 \mathrm{~b}$ & $1813 \mathrm{a}$ & $0,61 \mathrm{~b}$ \\
& $(18.83)$ & $(14.29)$ & $(26.97)$ \\
6 min. & $11,16 \mathrm{a}$ & $1807 \mathrm{a}$ & $0,73 \mathrm{a}$ \\
& $(15.07)$ & $(16.12)$ & $(15.22)$ \\
\hline
\end{tabular}

Averages followed by the same letter in the same column are statistically the same by the Tukey test at $95 \%$ reliability. Values in parentheses refer to the coefficient of variation in percentage.

Except for the MOE, the results of the factorial analysis indicated that there was influence of the pressing time on MOR, MOE and IB.

Table 7 shows the effects of pressing time on MOR, MOE and IB.

FLORESTA, Curitiba, PR, v. 49, n. 3, p. 383 - 390, jul/set 2019.

Iwakiri, S. et.al.

ISSN eletrônico 1982-4688

DOI: $10.5380 /$ rf.v49 i3.53238 
Table 7. Effects of pressing time on the mechanical properties of the panels.

Tabela 7. Efeitos da temperatura de prensagem sobre as propriedades mecânicas dos painéis.

\begin{tabular}{llll}
\hline Temperature & $\begin{array}{l}\text { MOR } \\
(\mathbf{M P a})\end{array}$ & $\begin{array}{l}\text { MOE } \\
(\mathbf{M P a})\end{array}$ & $\begin{array}{l}\text { IB } \\
(\mathbf{M P a})\end{array}$ \\
\hline $180^{\circ} \mathrm{C}$ & $11,63 \mathrm{a}$ & $1.911 \mathrm{a}$ & $0,68 \mathrm{a}$ \\
& $(13.97)$ & $(13.26)$ & $(16.56)$ \\
$200^{\circ} \mathrm{C}$ & $10,52 \mathrm{~b}$ & $1.848 \mathrm{a}$ & $0.60 \mathrm{~b}$ \\
& $(16.89)$ & $(12.64)$ & $(33.06)$ \\
$220^{\circ} \mathrm{C}$ & $9.22 \mathrm{c}$ & $1.720 \mathrm{~b}$ & $0.51 \mathrm{c}$ \\
& $(18.80)$ & $(15.19)$ & $(35.10)$ \\
\hline
\end{tabular}

Averages followed by the same letter of the same column are statistically the same by the Tukey test at 95\% reliability. Values in parentheses refer to the coefficient of variation in percentage.

The presented results of the factorial analysis in Table 7 indicated that it had influence of the pressing temperature on MOR, MOE and IB.

\section{DISCUSSIONS}

Small reductions in the density averages obtained for the panels were observed in respect to the nominal density calculated to $0.700 \mathrm{~g} . \mathrm{cm}^{-3}$. However, these differences were not statistically significant. The small reductions observed in the density of the panels produced can be attributed to the loss of material during the formation of the panels and return in thickness after hot pressing followed by packaging.

Additionally, the increase in the pressing time resulted in a reduction of WA2h and WA24h. The effects of the pressing times were not found for TS of the panels.

There was no uniform influence of the pressing temperature on the WA results. The temperature rises from 180 to $220^{\circ} \mathrm{C}$ increased WA2h, but there was a reduction in WA24h. However, for TS2h, lower values were obtained for lower temperatures, nonetheless, the effect of temperature was not found for TS24h.

The results of WA and TS obtained in this study were satisfactory when compared to some references presented in literature on particleboards of species from forest plantations, produced in the laboratory. Naumann et al. (2008) found for particleboards of Eucalyptus urophyllaand Schizolobium amazonicum, WA24h values of 97.2\% and 117.9\%, respectively; Iwakiri et al. (1996) found for particleboards of Pinus taedaand Eucalyptus dunnii, WA24h of $75.04 \%$ and $80.05 \%$, respectively; and Trianoski et al. (2016) found for panels produced with a mixture of Pinus taeda with Grevilea robust, values of 22.44 to $31.41 \%$ for WA24 h. With respect to TS24h, Naumann et al. (2008) found for panels of Eucalyptus urophylla and Schizolobium amazonicum, 30.50\% and $35.09 \%$, respectively; While Iwakiri et al. (1996) found for panels of Pinus taeda and Eucalyptus dunnii values of 30.50\% and 35.09\%; and Trianoski et al. (2016) found for panels produced with a mixture of Pinus taeda and Grevilea robust, values from 66.26 to $98.43 \%$ for TS24h.

Moreover, the increase in pressing time contributed to improve the results of MOR and IB, nevertheless did not significantly affect the MOE results. Regarding the effects of the pressing temperature, the best results of mechanical properties were obtained for panels produced with lower temperatures. Therefore, the results confirm the theories presented by Wilcox (1953) and Suleiman (1999), in which high press temperatures can contribute to the degradation of the crystalline structure of the cellulosic chain and affect the conductivity of heat, damaging the mechanical resistance of the panels.

Regarding the normative requirements of EN 312-3: 2003, all the treatments met the minimum values established for the MOE and IB whose values are respectively 1,600 MPa and 0,35 MPa. Regarding the MOR, no treatment met the minimum requirement of $13 \mathrm{MPa}$.

The results of WA and TS obtained in this research were satisfactory when compared to some references presented in literature on particleboards of species from forest plantations produced in the laboratory. In this way, Trianoski et al. (2011) found for particleboards produced with wood of Acrocarpus fraxinifolius, Melia azedarach

FLORESTA, Curitiba, PR, v. 49, n. 3, p. 383 - 390, jul/set 2019 Iwakiri, S. et.al. 
and Toona ciliata, values of IB of 1.50 MPa, 1.88 MPa and 1.64 MPa, respectively. In turn, Colli et al. (2010) found for particleboards produced with Schizolobium amazonicum an average value of 0.22 MPa. While Naumann et al. (2008) found for particleboards produced with timber of Eucalyptus urophylla and Schizolobium amazonicum values of 4.26 MPa and 13.96 MPa for MOR, and of $696 \mathrm{MPa}$ and 1,873 MPa for the MOE, respectively. Yet, Trianoski et al.(2011) found for particleboards produced with timber from Acorncarpus fraxinifolius, Melia azedarach and Toona ciliata MOR averages of 18.19 MPa, 18.56 MPa and 19.83 MPa, and MOE averages of $2.134 \mathrm{MPa}, 2.191 \mathrm{MPa}$ and $2.427 \mathrm{MPa}$, respectively for the three species studied; Finally, Trianoski et al. (2016), for the panels produced with a blend of Pinus taeda and Grevilea robust, values of MOR and MOE in the range of 7.67 to $13.85 \mathrm{MPa}$ and 1.381 to $1.635 \mathrm{MPa}$ were found, respectively.

\section{CONCLUSIONS}

The increase in the pressing time contributed to the reduction of the water absorption of the panels, however, did not significantly affect the swelling results in thickness. Regarding the temperature, the results indicated the possibility of pressing the panels with a lower temperature of $180^{\circ} \mathrm{C}$.

In addition, the increase in the pressing time resulted in higher values of flexural strength and perpendicular traction of the panels.

Furthermore, the increase in the pressing temperature adversely affected the mechanical properties of the panels, confirming the theories presented in the literature that high press temperatures can contribute to the degradation of the crystalline structure of the cellulosic chain and affect the heat conduction capacity, damaging the mechanical strength of the panels.

Based on the results obtained, it can be stated that the best combination of temperature and pressing time is $180^{\circ} \mathrm{C}$ and 6 minutes. To improve the results of swelling in thickness and resistance to static bending, which did not meet the normative requirements of EN 312-2003, a small increase in resin content is recommended.

\section{REFERENCES}

ALBUQUERQUE, C. E. C.; IWAKIRI, S. Interações de variáveis no ciclo de prensagem de aglomerados. Saarbrücken: Novas Edições Acadêmicas, 2016, 150 p.

COLlI, A.; VITAL, B.R.; CARNEIRO, A.C.O.; SILVA, J.C.; CARVALHO, A.N.M.L.; DELLA LUCIA, R.M. Propriedades de chapas fabricadas com partículas de madeira de paricá (Schizolobium amazonicum Huber ex. Ducke) e fibras de coco (cocos mucifera L.) Árvore, v. 34, n. 2, p. 333-338, 2010.

EUROPEAN COMITEE FOR STANDARDIZATION. EN 310. Determination of modulus of elasticity in bending and bending strength. Brussels. 2002.

EUROPEAN COMITEE FOR STANDARDIZATION. EN 312. Particleboards - specifications. Brussels. 2002. EUROPEAN COMITEE FOR STANDARDIZATION. EN 317. Determination of swelling in thickness after immersion in water. Brussels. 2002.

EUROPEAN COMITEE FOR STANDARDIZATION. EN 319. Determination of perpendicular tension strength. Brussels. 2002.

EUROPEAN COMITEE FOR STANDARDIZATION. EN 323. Determination of board density. Brussels. 2002.

IWAKIRI, S.; LATORRACA, J. V. F.; SILVA, D. A.; GABARDO, J. L.; KLITZKE, R. J.; FOFANO, A.; FABROWSKI, F.; INTERANMENSE, M. T. Produção de chapas de Madeira aglomerada de Pinus taeda taeda elliottii (Engelm) and Eucalyptus dunnii (Maid). Agrárias, v. 15, p. 33 - 41, 1996.

IWAKIRI, S. Painéis de madeira reconstituída. Curitiba: Fupef, 2005, 254 p.

MALONEY, T. M. Modern particleboard \& dry-process fiberboard manufacturing. San Francisco: Miller Freeman Inc.. 1993, 689 p.

MARRA, A. A. Technology of wood bonding: principles and practice. New York: Van Nostrand Reinhold, $1992,453 \mathrm{p}$.

FLORESTA, Curitiba, PR, v. 49, n. 3, p. 383 - 390, jul/set 2019

Iwakiri, S. et.al.

ISSN eletrônico 1982-4688

DOI: $10.5380 /$ rf.v49 i3.53238 
MOSLEMI, A. A. Particleboard. Illinois: Southern Illinois University Press, 1974. 245 p.

NAUMANN, R. B.; VITAL, B. R.; CARNEIRO, A. C. O.; DELLA LUCIA, R. M.; SILVA, J. C.; CARVALHO, A. M. M. L.; COLLI, A. Propriedades de chapas fabricadas com partículas de Madeira de Eucalyptus urophylla S.T.Blake e de Schizolobium amazonicum Herb. Àrvore, v. 32, p. 1143 - 1150, 2008.

SULEIMAN, B. M. Thermal conductivity of wood. Wood Science and Technology, v. 33, n. 6, p. 465 - 473 , 1999.

TRIANOSKI, R.; IWAKIRI, S.; MATOS, J. L. M. Potential use of planted fast-growing species for production of particleboard. Journal of Tropical Forest Science, v. 23, p. $311-317,2011$.

TRIANOKSI, R.; PICCARDI, A. B. R.; IWAKIRI, S.; MATOS, J. L. M.; BONDUELLE, G. M. Incorporação de Grevilea robusta na produção de painéis aglomerados de Pinus. Floresta e Ambiente, v. 23, p. 278 - 285, 2016.

WILCOX, H. Interrelationship of temperature, pressure and pressing time in the production of hardboard from Douglas-fir fiber: The effects of these variables on hardboard properties. TAPPI, v. 36, n. 2, p. 89 - 94, 1953. 